\title{
Hepatitis C virus seroconversion among HIV-positive men who have sex with men with no history of injection drug use: Results from a clinical HIV cohort
}

\author{
Ann N Burchell PhD ${ }^{1,2}$, Sandra L Gardner PhD ${ }^{1,2}$, Tony Mazzulli MD ${ }^{3,4,5}$, Michael Manno MSc ${ }^{1}$, Janet Raboud PhD ${ }^{2,6}$ \\ Vanessa G Allen MD³, Ahmed M Bayoumi MD MSc ${ }^{7,8,9}$, Rupert Kaul MD PhD ${ }^{9}$, Frank McGee ${ }^{10}$, Peggy Millson MD², \\ Robert S Remis MD MPH ${ }^{2,3}$, Wendy Wobeser MD MSc ${ }^{11,12}$, Curtis Cooper MD ${ }^{13,14}$, Sean B Rourke PhD ${ }^{1,7,15}$ \\ on behalf of the Ontario HIV Treatment Network Cohort Study Team*
}

\begin{abstract}
AN Burchell, SL Gardner, T Mazzulli, et al. Hepatitis C virus seroconversion among HIV-positive men who have sex with men with no history of injection drug use: Results from a clinical HIV cohort. Can J Infect Dis Med Microbiol 2015;26(1):17-22.
\end{abstract}

BACKGROUND: Internationally, there is a growing recognition that hepatitis $\mathrm{C}$ virus (HCV) may be sexually transmitted among HIVpositive men who have sex with men (MSM).

OBJECTIVE: To report the first Canadian estimate of HCV seroincidence in 2000 to 2010 and its risk factors among HIV-positive MSM with no known history of injection drug use.

METHODS: Data from the Ontario HIV Treatment Network Cohort Study, an ongoing cohort of individuals in HIV care in Ontario, were analyzed. Data were obtained from medical charts, interviews and record linkage with the provincial public health laboratories. The analysis was restricted to $1534 \mathrm{MSM}$ who did not report injection drug use and had undergone $\geq 2 \mathrm{HCV}$ antibody tests, of which the first was negative (median 6.1 person-years [PY] of follow-up; sum 9987 PY). RESULTS: In 2000 to 2010, $51 \mathrm{HCV}$ seroconversions were observed, an overall incidence of 5.1 per 1000 PY (95\% CI 3.9 to 6.7). Annual incidence varied from 1.6 to 8.9 per $1000 \mathrm{PY}$, with no statistical evidence of a temporal trend. Risk for seroconversion was elevated among men who had ever had syphilis (adjusted HR 2.5 [95\% CI 1.1 to 5.5) and men who had acute syphilis infection in the previous 18 months (adjusted HR 2.8 [95\% CI 1.0 to 7.9]). Risk was lower for men who had initiated antiretroviral treatment (adjusted HR 0.49 [95\% CI 0.25 to 0.95]). There were no statistically significant effects of age, ethnicity, region, CD4 cell count or HIV viral load.

CONCLUSIONS: These findings suggest that periodic HCV rescreening may be appropriate in Ontario among HIV-positive MSM. Future research should seek evidence whether syphilis is simply a marker for high-risk sexual behaviour or networks, or whether it potentiates sexual HCV transmission among individuals with HIV.

Key Words: Hepatitis C virus; HIV; Incidence; Men who have sex with men; Syphilis
La séroconversion au virus de l'hépatite $\mathrm{C}$ chez des hommes positifs au VIH qui ont des relations sexuelles avec des hommes sans antécédents de consommation de drogues injectables : les résultats d'une cohorte de VIH clinique

HISTORIQUE : Sur la scène internationale, il apparaît de plus en plus clairement que le virus de l'hépatite C (VHC) peut être transmis sexuellement entre hommes positifs au VIH ayant des relations sexuelles avec des hommes (HARSAH).

OBJECTIF : Rendre compte de la première estimation canadienne de la séro-incidence de VHC entre 2000 et 2010 et de ses facteurs de risque chez les HARSAH positifs au VIH sans antécédents connus de consommation de drogues injectables.

MÉTHODOLOGIE : Les chercheurs ont analysé les données de l'Ontario HIV Treatment Network Cohort Study, une cohorte continue de personnes soignées pour le VIH en Ontario. Ils ont tiré les données de dossiers médicaux, d'entrevues et de liens entre les dossiers et les laboratoires provinciaux de santé publique. Ils ont restreint l'analyse à 1534 HARSAH qui ne déclaraient pas consommer de drogues injectables et qui avaient subi au moins deux tests d'anticorps du VHC, dont le premier était négatif (suivi médian de 6,1 années-personne [AP]; somme de 9987 AP).

RÉSULTATS : De 2000 à 2010, les chercheurs ont observé 51 cas de séroconversion au $\mathrm{VHC}$, pour une incidence globale de 5,1 cas sur $1000 \mathrm{AP}(95 \%$ IC 3,9 à 6,7). L'incidence annuelle variait entre 1,6 et 8,9 cas sur $1000 \mathrm{AP}$, sans preuve statistique de tendance temporelle. Le risque de séroconversion était élevé chez les hommes qui n'avaient jamais eu la syphilis (RR rajusté 2,5 [95\% IC 1,1 à 5,5) et chez les hommes qui avaient eu une infection aiguë par la syphilis dans les 18 mois précédents (RR rajusté 2,8 [95\% IC 1,0 à 7,9]). Le risque était plus faible chez les hommes qui avaient entrepris un traitement antirétroviral (RR rajusté 0,49 [95 \% IC 0,25 à 0,95]). L'âge, l'ethnie, la région, la numération des cellules CD4 et la charge virale du VIH n'avaient pas d'effet statistiquement significatif.

CONCLUSIONS : D'après ces observations, il serait judicieux de procéder au dépistage périodique du VHC chez les HARSAH positifs au VIH de l'Ontario. De prochaines recherches devraient viser à établir si la syphilis est un simple marqueur de comportements ou de réseaux sexuels à haut risque ou si elle potentialise la transmission sexuelle du VHC chez les personnes atteintes du VIH.

\footnotetext{
* Members are listed in the Acknowledgements section

${ }^{1}$ Ontario HIV Treatment Network; ${ }^{2}$ Dalla Lana School of Public Health, University of Toronto; ${ }^{3}$ Public Health Laboratories, Public Health Ontario; ${ }^{4}$ Department of Microbiology, Mount Sinai Hospital; ${ }^{5}$ Department of Laboratory Medicine and Pathobiology, University of Toronto; ${ }^{6}$ Toronto General Research Institute, University Health Network; ${ }^{7}$ Centre for Research on Inner City Health, The Keenan Research Centre in the Li KaShing Knowledge Institute, St Michael's Hospital; ${ }^{8}$ Institute of Health Policy, Management and Evaluation, University of Toronto; ${ }^{9}$ Department of Medicine, University of Toronto; ${ }^{10} \mathrm{AIDS}$ Bureau, Ontario Ministry of Health and Long-Term Care; ${ }^{11}$ Hotel Dieu Hospital; ${ }^{12}$ Queen's University, Kingston; ${ }^{13}$ Ottawa Hospital; ${ }^{14}$ University of Ottawa, Ottawa; ${ }^{15}$ Department of Psychiatry, University of Toronto Correspondence: Dr Ann N Burchell, Ontario HIV Treatment Network, Suite 600, 1300 Yonge Street, Toronto, Ontario M4T 1 X3.

Telephone 416-642-6486, fax 416-640-4245, e-mail aburchell@ohtn.on.ca
} 
$\mathrm{O}$ utbreaks of hepatitis $\mathrm{C}$ virus (HCV) among HIV-positive men who have sex with men (MSM) with no history of injection drug use have been reported from Europe, North America, Australia and Asia (1-6). Although heterosexual HCV transmission is considered to be inefficient (7-9), increasing evidence suggests that sexual transmission occurs among HIV-positive MSM (6). Possible explanations include sexual networks, behavioural factors and biological cofactors, with HCV viral sequence analysis supporting the theory that the HCV epidemic has been driven by changes in sexual behaviour among MSM after 1996, the year of the introduction of combination antiretroviral treatment (ART) (6). Behavioural factors include serosorting (the practice of HIV-positive MSM selectively having unprotected sex with other HIV-positive men); the more common practice of engaging in anal sex because rectal mucosa may be more susceptible than vaginal mucosa; traumatic sexual practices, such as 'fisting', which rupture the skin and cause bleeding; and the use of noninjection recreational drugs (6). Biologically, HIV may increase HCV susceptibility and infectiousness (6). Coinfection with other mucosally disruptive sexually transmitted infections may serve as cofactors (6).

In Canada, the prevalence of $\mathrm{HCV}$ in the general population is estimated to be $0.8 \%$, with an annual incidence of 33.7 per 100,000 as of 2009 (10). The majority of infections have been attributed to the sharing of injection drug use equipment, and receipt of blood and blood products before the introduction of HCV screening in 1990. Until recently, sexual transmission was considered to be a theoretically possible but rare mode of transmission in Canada. No HCV acquisition was detected among noninjecting MSM in a large, primarily HIV-negative cohort in Montreal in 1996 to 2001 (11). Anecdotally, Canadian HIV care physicians have not noticed an increase in HCV diagnoses among MSM patients (12). However, ongoing vigilance is important, because if the rate of HCV infection is sufficiently high, occasional screening among HIV-positive MSM would be cost effective (13). Timely diagnosis may prevent further transmission, and may guide treatment and care decisions, because HCV coinfection may complicate HIV therapy $(14,15)$.

We estimated HCV seroincidence among HIV-positive MSM in Ontario with no known history of injection drug use. We hypothesized that syphilis infection would predict HCV seroconversion, because it would be a proxy measure of high-risk sexual behaviour and/or a cofactor for acquisition.

\section{METHODS}

The source of the data analyzed in the present study was from the Ontario HIV Treatment Network Cohort Study (OCS) (16). The cohort's source population consists of individuals $\geq 16$ years of age diagnosed with HIV infection who receive medical care at specialty HIV clinics. The 10 participating clinics serve more than three-quarters of HIV patients undergoing viral load testing in the province. Enrollment and ongoing participation in the cohort was voluntary. All participants provided written informed consent. Clinical data obtained as part of participants' routine health care were abstracted from clinic records. From 1995 to 2007, participants self-completed a questionnaire at enrollment. Since 2008, participants have been interviewed annually (16). The study protocol, research instruments and forms received ethical approval from the University of Toronto Human Subjects Review Committee (Toronto, Ontario) and from the individual study sites.

\section{Measurement of coinfection}

Testing data were obtained for HIV viral load, HCV and syphilis through record linkage with the provincial Public Health Ontario Laboratories (PHOL). In Ontario, serological screening for hepatitis virus infections can be performed by private laboratories, hospital laboratories or at the PHOL. The PHOL conduct virtually all confirmatory HCV diagnostic serology in Ontario and virtually all HCV-RNA viral load monitoring among the chronically infected. The PHOL is the sole provider of HIV viral load and syphilis serological tests (17).

\section{Analysis}

As of December 2011, 5933 participants had enrolled. For the present study, the cohort was limited to 3453 male participants who reported sex with men as their HIV risk factor and/or who self-identified as homosexual or bisexual, did not report injection drug use as their HIV risk factor and did not report drug injection following HIV diagnosis. The cohort was further limited to 2761 men who were under observation in 2000 to 2010 and for whom there was successful record linkage to the HIV viral load database at the PHOL, meaning that any confirmatory or follow-up HCV testing should have been observable. Finally, the cohort was then limited to 1534 men who had at least two linked HCV test records from the PHOL, for which the first was HCV negative; $\chi^{2}$ and $t$ tests were used to compare the characteristics of the 1227 men who did not meet this criterion with the 1534 men who did. All statistical analyses were conducted using SAS version 9.3 (SAS Institute Inc, USA). All P values were two-sided and statistical significance was determined using the traditional $\mathrm{P}<0.05$.

The incidence density of HCV seroconversion per 1000 personyears (PY) of follow-up was calculated. Person-time was calculated for each subject beginning at the later of the first $\mathrm{HCV}$-antibody negative result, HIV diagnosis date, or January 1, 2000, and ended at the earlier of the last known date of follow-up, date of death (if applicable) or, for cases, the date of the first HCV-antibody positive test. Similarly, the annual incidence density was calculated as the number of new HCV diagnoses during each calendar year per 1000 PY of follow-up in that year. Poisson regression was used for all incidence density calculations and these were reported with $95 \%$ CIs.

Risk factors for HCV seroconversion were identified using Cox proportional hazards methods and results are reported as HRs. The effects of the following factors were explored: age; region of residence; ethnicity and time-updated values of CD4 cell count; HIV viral load; whether ART had been initiated; previous reactive syphilis serology and recent diagnosis of acute syphilis infection (defined as a reactive treponemal test and rapid plasma reagin titre $\geq 1: 16$, any reactive syphilis test following a previously negative test result, or a fourfold rise in rapid plasma reagin titre for those whose previous syphilis tests were reactive). A multivariable model was first built containing all considered risk factors, then those that were neither associated with HCV seroconversion nor required for adjustment of the remaining risk factors were excluded.

Various sensitivity analyses were conducted. HCV incidence was re-estimated including the additional 746 men who were tested for $\mathrm{HCV}$ antibody only once and were nonreactive; it was assumed that these men remained HCV-negative for the duration of follow-up. HR estimates were also recalculated in a Cox model for which the seroconversion event date was reassigned as the midpoint between the last $\mathrm{HCV}$ antibody-negative and first $\mathrm{HCV}$ antibody-positive test, to account for interval censoring. Finally, the estimates of HCV seroincidence were compared among men who were interviewed in 2008 to 2010 with men who were not interviewed (due to death or loss to follow-up before the introduction of the interview, or participation at one clinic that did not administer interviews). It was hypothesized that injection drug use would be better reported via interview and, thus, that the estimate of $\mathrm{HCV}$ seroincidence should be higher among uninterviewed men due to misclassification as noninjectors. The rate of HCV seroincidence among the 174 men who did not report sex with men and 233 women in the cohort who met all other criteria for analysis (except MSM status) was also calculated. Because sexual HCV transmission among individuals with HIV has been primarily reported among MSM (6), it was hypothesized that HCV seroincidence would be lower among heterosexual men and women.

\section{RESULTS}

Among the 1534 men who were included in the analysis of HCV seroconversion, men were, on average, 41 years of age, white and living in Toronto at baseline (Table 1). Most had initiated ART. The median HIV viral load was 759 copies/mL and the mean CD4 cell count was 421 cells $/ \mathrm{mm}^{3}$. The included participants were slightly younger, were less likely to live in Ottawa, were more likely to be of nonwhite race, were diagnosed more recently and had higher viral loads compared with the 1227 men who would have been eligible for 
TABLE 1

Characteristics of men who have sex with men with no history of injection drug use who were included and excluded from the analysis of hepatitis C virus (HCV) seroincidence, Ontario HIV Treatment Network Cohort Study, 2000 to 2010

\begin{tabular}{|c|c|c|c|}
\hline Characteristic & $\begin{array}{l}\text { Included } \\
(n=1534)\end{array}$ & $\begin{array}{l}\text { Excluded } \\
(n=1227)\end{array}$ & $\mathbf{P}^{\dagger}$ \\
\hline \multicolumn{4}{|l|}{ Age at baseline ${ }^{*}$, years } \\
\hline$<30$ & $150(9.8)$ & $92(7.5)$ & 0.14 \\
\hline $30-39$ & $541(35.3)$ & $425(34.6)$ & \\
\hline $40-49$ & $584(38.1)$ & $482(39.3)$ & \\
\hline$\geq 50$ & $259(16.9)$ & $228(18.6)$ & \\
\hline Mean \pm SD & $41 \pm 9.4$ & $42 \pm 9.4$ & 0.009 \\
\hline \multicolumn{4}{|l|}{ Region (Ontario) } \\
\hline Toronto & $1142(74.4)$ & $755(61.5)$ & $<0.0001$ \\
\hline Ottawa & $80(5.2)$ & $205(16.7)$ & \\
\hline Other & $312(20.3)$ & $267(21.8)$ & \\
\hline \multicolumn{4}{|l|}{ Race $^{\ddagger}$} \\
\hline White & $1144(74.6)$ & $971(79.1)$ & 0.009 \\
\hline Black & $72(4.7)$ & $37(3.0)$ & \\
\hline Aboriginal & $121(7.9)$ & $70(5.7)$ & \\
\hline Other race & $194(12.7)$ & $149(12.1)$ & \\
\hline $\begin{array}{l}\text { Year of HIV diagnosis, } \\
\text { median (IQR) }\end{array}$ & $1996(1990-2003)$ & 1993 (1989-1999) & $<0.0001$ \\
\hline $\begin{array}{l}\text { Initiated antiretroviral } \\
\text { treatment at baseline }\end{array}$ & $963(62.8)$ & $800(65.2)$ & 0.19 \\
\hline $\begin{array}{l}\text { Initiated antiretroviral } \\
\text { treatment as of last } \\
\text { follow-up }\end{array}$ & $1419(92.5)$ & $1156(94.2)$ & 0.07 \\
\hline $\begin{array}{l}\text { CD4 cell count } / \mathrm{mm}^{3} \text { at } \\
\text { baseline }{ }^{*}, \text { mean } \pm \text { SD }\end{array}$ & $421 \pm 260$ & $403 \pm 254$ & 0.13 \\
\hline $\begin{array}{c}\log _{10} \text { viral load at base- } \\
\text { line*, median (IQR) }^{*} \text {, }\end{array}$ & $2.88(1.69-4.53)$ & $2.42(1.69-4.14)$ & 0.0005 \\
\hline \multicolumn{4}{|l|}{$\begin{array}{l}\text { Ever HCV-positive at last } \\
\text { follow-up }\end{array}$} \\
\hline No & $1483(96.7)$ & $1132(92.3)$ & $<0.0001$ \\
\hline Yes & $51(3.3)$ & $95(7.7)$ & \\
\hline
\end{tabular}

Data presented as $n(\%)$ unless otherwise indicated. *Baseline was defined as the later of the first HCV-negative test, the first HIV-positive date, or January 1 , 2000; ${ }^{\top} P$ values were calculated using $\chi^{2}$ tests for categorical variables, Wilcoxon signed-rank for medians or Student's tests for means, as appropriate; ${ }^{ \pm}$Excludes 15 men with unknown race. IQR Interquartile range

inclusion in the analysis if it were not for the fact that they had not been tested for HCV at least twice with the first test being negative (Table 1). Among these 1227 excluded men, 746 were tested only once and were $\mathrm{HCV}$-negative, 95 tested positive for $\mathrm{HCV}$ at their first test and the remainder had no record of ever being tested for HCV.

Men contributed a median of 6.1 PY (interquartile range [IQR] 3.7 to 10.1) of follow-up to the analysis of HCV seroconversion for a total of 9987 PY. The first HCV-negative test occurred a median of 3.6 years after HIV diagnosis (IQR 0.2 to 10.2 ); all but four patients had their first HCV-negative test post-HIV diagnosis. Men underwent $\mathrm{HCV}$ testing a median of two times ( 75 th percentile four times). The median intertest interval was 2.2 years (IQR 1.0 to 4.9 ) and the median number of HCV tests per year was 0.4 (IQR 0.2 to 0.9 ).

A total of 51 seroconversions were observed. The first HCVpositive test occurred a median of 9.7 years after HIV diagnosis (IQR 4.5 to 15.0 ) and 2.7 years after the first HCV-negative test (IQR 0.5 to 5.5). The majority of cases (45 of 51 [89\%]) had at least one PHOL record for HCV viral load following the seroconversion date; of these $45,62 \%$ had detectable viral load, $24 \%$ had undetectable viral load and for the remainder the result was missing. The overall HCV seroincidence was 5.1 per 1000 PY (95\% CI 3.9 to 6.7) with annual rates

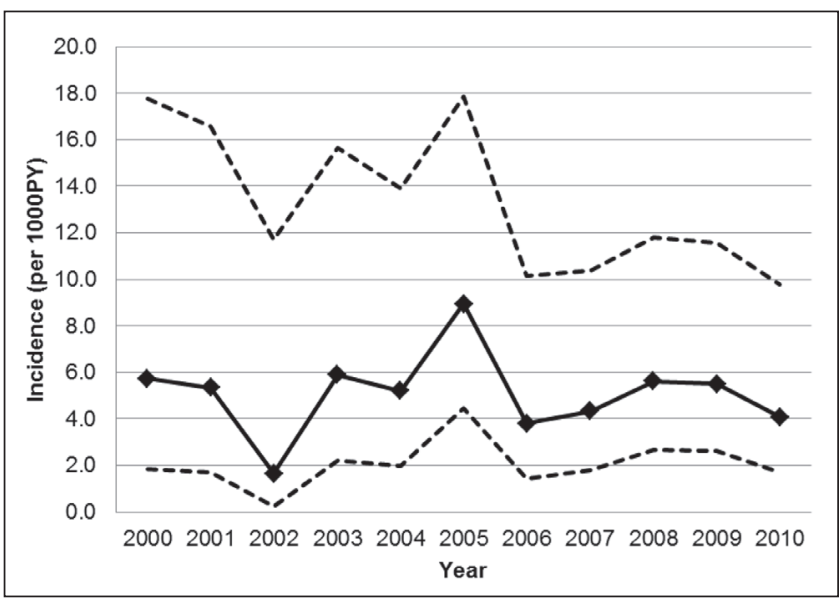

Figure 1) Hepatitis $C$ virus seroincidence among HIV-positive men who have sex with men in Ontario, 2000 to 2010. Dashed lines represent 95\% CIs

that varied from 1.6 to 8.9 per 1000 PY, with no evidence of a temporal trend (Figure 1). In a sensitivity analysis that additionally included person time from the 746 men who tested negative for HCV but who were never tested again, under the assumption that they remained negative, HCV seroincidence was 3.6 per $1000 \mathrm{PY}(95 \% \mathrm{CI}$ 2.7 to 4.7); this estimate provides a plausible lower bound of the underlying true rate.

The strongest risk factor for HCV seroconversion was having ever had reactive syphilis serology (Table 2). An elevation of risk was also observed for men who had evidence of acute syphilis infection within the past 18 months, although the 95\% CI included 1.0 (Table 2). Among cases, 20\% (10 of 51) had a history of reactive syphilis serology before their first HCV antibody positive test and, among these, 60\% had evidence of acute syphilis infection within 36 months of their $\mathrm{HCV}$ diagnosis. In a sensitivity analysis using the midpoint date as the event date for cases, the adjusted HRs for ever having syphilis increased from 2.5 (95\% CI 1.1 to 5.5 ) to 2.8 (95\% CI 1.2 to 6.4 ), and the adjusted HR for acute syphilis within the past 18 months declined from 2.8 (95\% CI 1.0 to 7.9 ) to 2.0 (95\% CI 0.63 to 6.6 ).

There was an effect of ART, such that men who had initiated treatment were less likely to experience HCV seroconversion (adjusted HR 0.49 [95\% CI 0.25 to 0.95) (Table 2). The magnitude of the HR did not diminish with adjustment for age or time since diagnosis (data not shown), but did diminish to 0.57 (95\% CI 0.30 to 1.1 ) in sensitivity analysis using the midpoint date method. No other examined covariates modified the risk of HCV seroconversion in the primary analysis, in the sensitivity analyses using the midpoint estimate of the seroconversion date or in the analysis that included men who tested HCV negative but who were never tested again (data not shown).

Finally, analyses were conducted in an attempt to quantify the degree of ascertainment bias due to unreported injection drug use (Table 3). Although there was insufficient precision to declare rates statistically significantly different between groups, the incidence was observed to be higher among men who were not interviewed compared with men who were, and the rate among female and heterosexual male participants with no history of injection drug use was one-half the rate of MSM.

\section{DISCUSSION}

We analysed data from MSM in HIV care in Ontario from 2000 to 2010 and observed that, among men with no recorded history of injection drug use, the incidence of HCV seroconversion was 5.1 per 1000 PY (95\% CI 3.9 to 6.7$)$, which is 15 times higher than that the rate of 0.337 per 1000 observed in the general population in 2009 (10). It is, however, consistent with rates reported among HIV-positive urban MSM internationally, which range from 0 to 12.3 per $1000 \mathrm{PY}$, and average 6.08 per 1000 PY (95\% CI 5.18 to 6.99) (1). At such a rate, 
TABLE 2

Risk factors for hepatitis C virus seroconversion among
HIV-positive men who have sex with men in Ontario,
2000 to 2010 Unadjusted HR Adjusted $\mathrm{HR}^{\dagger}$ Adjusted $\mathrm{HR}^{\dagger}$

\begin{tabular}{|c|c|c|c|}
\hline & $(95 \% \mathrm{Cl})$ & $(95 \% \mathrm{Cl})$ & $(95 \% \mathrm{CI})$ \\
\hline \multicolumn{4}{|l|}{ Age, years } \\
\hline$<30$ & 1.00 & & \\
\hline $30-39$ & $0.83(0.31-2.2)$ & & \\
\hline $40-49$ & $0.72(0.27-2.0)$ & & \\
\hline$\geq 50$ & $1.01(0.35-3.0)$ & & \\
\hline \multicolumn{4}{|l|}{ Region } \\
\hline Toronto & 1.00 & 1.00 & 1.00 \\
\hline Ottawa & $1.8(0.63-5.0)$ & $2.0(0.69-5.5)$ & $1.9(0.68-5.4)$ \\
\hline Other & $1.2(0.64-2.3)$ & $1.4(0.73-2.7)$ & $1.4(0.71-2.6)$ \\
\hline \multicolumn{4}{|l|}{ Race } \\
\hline White & 1.00 & & \\
\hline Black & $0.86(0.21-3.59)$ & & \\
\hline Aboriginal & $1.6(0.66-3.71)$ & & \\
\hline Other & $0.93(0.39-2.21)$ & & \\
\hline \multicolumn{4}{|l|}{$\mathrm{CD} 4$ cell count $/ \mathrm{mm}^{3 *}$} \\
\hline$<200$ & 1.00 & & \\
\hline $200-499$ & $0.78(0.36-1.7)$ & & \\
\hline$\geq 500$ & $0.66(0.30-1.5)$ & & \\
\hline \multicolumn{4}{|l|}{ HIV viral load* } \\
\hline Detectable & 1.00 & & \\
\hline Undetectable & $0.90(0.51-1.6)$ & & \\
\hline \multicolumn{4}{|l|}{ Initiated ART* } \\
\hline No & 1.00 & 1.00 & 1.00 \\
\hline Yes & $0.49(0.26-0.95)$ & $0.49(0.25-0.95)$ & $0.49(0.25-0.95)$ \\
\hline $\begin{array}{l}\text { Each additional year } \\
\text { since HIV diagnosis* }\end{array}$ & $0.98(0.94-1.03)$ & & \\
\hline \multicolumn{4}{|c|}{ Ever had reactive syphilis serology* } \\
\hline No & 1.00 & 1.00 & \\
\hline Yes & $2.4(1.1-5.5)$ & $2.5(1.1-5.5)$ & \\
\hline \multicolumn{4}{|c|}{ Acute syphilis within 18 months* } \\
\hline No & 1.00 & & 1.00 \\
\hline Yes & $2.9(1.0-8.0)$ & & $2.8(1.0-7.9)$ \\
\hline
\end{tabular}

*Time-varying covariates were updated at each seroconversion event time; †Multivariate Cox proportional hazards model including all covariates shown. ART Antiretroviral therapy

the burden of HCV infection and its sequelae may become considerable. By the end of follow-up, 3.3\% of participants were coinfected with HCV. This prevalence is similar to that found in a Canadian venue-based study of MSM, which found that HCV coinfection was present in $4 \%$ of HIV-positive MSM who never injected drugs (10).

Men who had ever had syphilis were more than twice as likely to acquire HCV (adjusted HR 2.5 [95\% CI 1.1 to 5.5]). We also observed an elevation of risk for men with recent acute syphilis within the past 18 months that approached statistical significance (adjusted HR 2.8 [95\% CI 1.0 to 7.9]) but the 95\% CI included one, such that we were unable to reject the null hypothesis of no association for recent syphilis. Past syphilis has been noted as a risk factor in univariate analysis of case-control studies in the United Kingdom (18), United States (3) and Germany (19). The Swiss HIV Cohort found a doubling of HCV seroincidence among MSM with past syphilis (adjusted HR 2.1 [95\% CI 1.4 to 3.2]) (20). In a Taiwanese analysis of HIV patients, syphilis infection within the past six months was associated with a 7.7-fold increase in odds of HCV seroconversion (21). Syphilis can be considered a proxy measure of high-risk sexual behaviour. It is also possible that syphilitic ulcers potentiate $\mathrm{HCV}$ acquisition due to disruption of mucosa $(6,20)$. By analogy, syphilis is an established HIV
TABLE 3

Hepatitis C virus seroincidence among HIV-positive men who have sex with men, by method of ascertainment of injection drug use history, and compared with women and heterosexual men

\begin{tabular}{lc}
\hline & $\begin{array}{c}\text { Incidence per } \\
1000 \text { person- } \\
\text { years } \\
(95 \% \mathbf{C l})\end{array}$ \\
\hline Men who have sex with men with no record of injection drug use & $5.1(3.9-6.7)$ \\
Completed one or more interviews & $5.0(3.7-6.7)$ \\
Were not interviewed & $6.4(2.6-15.3)$ \\
Female participants with no record of injection drug use & $2.6(1.1-6.3)$ \\
Male participants who completed one or more interviews and & $2.1(0.8-7.9)$ \\
had no record of sex with men or injection drug use & \\
\hline
\end{tabular}

cofactor that increases the risk of HIV acquisition several fold (22). There is no evidence that syphilis alters the biological characteristics of HCV; however, this has not been thoroughly studied. An alternative, noncausal explanation for the association between syphilis and HCV may be that a syphilis episode prompts a thorough sexually transmitted infection (STI) work-up, including HCV testing, or vice versa, such that HCV acquisition may precede syphilis infection. We observed that syphilis testing occurred at the time of HCV antibody testing in one-third of diagnosed cases. In sensitivity analysis using the midpoint method to impute event dates, the magnitude of the HR estimate for recent syphilis decreased from 2.8 to 2.0, suggesting that this diagnostic work-up bias may have been present. Our observations require confirmation given our limited precision to quantify risk associated with recent syphilis.

Men who had not yet initiated ART were twice as likely to acquire $\mathrm{HCV}$, a finding that was not due to confounding by age or time since HIV diagnosis. The finding would be consistent with the biological hypothesis that HIV increases susceptibility to HCV, such that suppression of viral load may mitigate this effect (6). However, we observed no direct effect of HIV viral load on HCV risk. Other clinical cohorts in Switzerland (20) and Germany (19) have not observed differences between those receiving and not receiving antiretroviral therapy, suggesting that our finding may be anomalous, unique to our setting or confounded. Further study would be necessary to establish the mechanism for this association, which could be due to behavioural or sexual network factors. Lack of antiretroviral use is associated with behaviours that heighten risk for HCV infection. There is evidence that HCV RNA levels are higher for individuals not on HIV antiretroviral therapy, which would increase risk for onward HCV transmission to partners (23).

The strengths of our analysis included a large sample size, extended follow-up period and use of data from a generally representative cohort of individuals with HIV in Ontario based on characteristics of cumulative HIV diagnoses in Ontario in terms of sex, geographic region, age at diagnosis and HIV exposure category (24). Nevertheless, OCS participants under-represent the recently diagnosed and, compared with nonvolunteer patients at these clinics, participants tend to be older, have been diagnosed for longer and are generally healthier, as measured by CD4 cell count and viral load (25). There was the potential for referral bias given that $\mathrm{HCV}$ tests were ordered for clinical care purposes rather than at standardized intervals. MSM participants who did not meet analysis inclusion criteria tended to live in Ottawa, the second-largest city in Ontario, which has experienced high HIV and $\mathrm{HCV}$ infection rates among people who inject drugs compared with the remainder of the province (26). As of the last follow-up, HCV coinfection was higher among excluded men $(7.7 \%)$ than among the men who were included (3.3\%); HCV-positive men in the former group were men that tested HCV positive on their first test. All men included in our primary analysis were HCV negative at their first test; 
however, the fact that HCV retesting was ordered suggests that physicians may have considered these men to be at higher risk for infection, which may have biased our incidence estimates. Such bias due to testing patterns is likely to have diminished with time, because HCV testing has become more frequent in our setting; by 2010, $85 \%$ of patients were tested at least once (27). We cannot rule out the possibility that our calculations excluded some undiagnosed seroconversions for men who had not yet been retested for HCV. The rates of HCV seroincidence we observed were consistent with those reported internationally (1), which indicates that bias, if present, was unlikely to be extreme.

We cannot exclude the possibility of $\mathrm{HCV}$ acquisition via unreported injection drug use. Compared with MSM who underwent in-depth interviewing, we observed a higher point estimate for HCV seroconversion among men whose assessment of injection drug use history status was based only on a brief, self-completed questionnaire. This suggests that some proportion of $\mathrm{HCV}$ cases was likely due to acquisition via unreported sharing of drug use equipment. Nevertheless, the observed association with syphilis infection would be consistent with some sexual transmission.

Our findings have implications for best practices for HCV screening. Current guidelines recommend HCV testing at HIV diagnosis $(28,29)$. Subsequent screening is warranted among HIV-positive MSM who report high-risk sexual behaviour and/or concomitant ulcerative STIs including syphilis (29). Regardless of reported sexual risk behaviour, our observed rate of HCV seroconversion combined with mathematical modelling work by Linas et al (13) suggest that it would be cost effective to conduct rescreening with tests for alanine aminotransferase every six months and HCV antibody annually, as recommended by European AIDS Treatment Network guidelines (30). The higher HCV rate we observed among men who had not yet initiated ART suggests that repeated screening may be especially prudent during this time. Repeated screening for HCV RNA is also warranted for patients who have been successfully treated for HCV infection because reinfection can occur $(6,31)$. Patient education and safer sex counselling to prevent coinfection with STIs remains necessary, especially among men who have only HIV-positive sex partners and may believe that condoms are unnecessary. Finally, future research should seek evidence regarding whether syphilis is simply a marker of high-risk sexual behaviour or networks, or whether it potentiates sexual HCV transmission among individuals with HIV.

\section{REFERENCES}

1. Yaphe S, Bozinoff N, Kyle R, et al. Incidence of acute hepatitis C virus infection among men who have sex with men with and without HIV infection: A systematic review. Sex Transm Infect 2012;88:558-64.

2. Van der Helm JJ, Prins M, del Amo J, et al. The hepatitis C epidemic among HIV-positive MSM: Incidence estimates from 1990 to 2007. AIDS Lond Engl 2011;25:1083-91.

3. Fierer DS. Epidemic of sexually transmitted hepatitis c virus infection among HIV-infected men. Curr Infect Dis Rep 2010;12:118-25.

4. Gamage DG, Read TR, Bradshaw CS, et al. Incidence of hepatitis-C among HIV infected men who have sex with men (MSM) attending a sexual health service: A cohort study. BMC Infect Dis 2011;11:39.

5. Van de Laar TJ, Matthews GV, Prins M, et al. Acute hepatitis C in HIV-infected men who have sex with men: An emerging sexually transmitted infection. AIDS Lond Engl 2010;24:1799-812.

6. Bradshaw D, Matthews G, Danta M. Sexually transmitted hepatitis C infection: The new epidemic in MSM? Curr Opin Infect Dis 2013;26:66-72.

7. Vandelli C, Renzo F, Romanò L, et al. Lack of evidence of sexual transmission of hepatitis $\mathrm{C}$ among monogamous couples: Results of a 10-year prospective follow-up study. Am J Gastroenterol 2004;99:855-9.

8. Wyld R, Robertson JR, Brettle RP, et al. Absence of hepatitis C virus transmission but frequent transmission of HIV-1 from sexual contact with doubly-infected individuals. J Infect 1997;35:163-6.
ACKNOWLEDGEMENTS: The OHTN Cohort Study Team consists of Dr Sean B Rourke (Principal Investigator, University of Toronto and OHTN), Dr Ann Burchell (Co-Principal Investigator, OHTN), Dr Sandra Gardner (OHTN), Dr Sergio Rueda (OHTN), Dr Ahmed Bayoumi and Dr Kevin Gough, St Michael's Hospital; Dr Jeffrey Cohen, Windsor Regional Hospital; Dr Curtis Cooper, Ottawa General Hospital; Dr Don Kilby, University of Ottawa Health Services; Dr Mona Loutfy and Dr Fred Crouzat, Maple Leaf Medical Clinic; Dr Anita Rachlis and Dr Nicole Mittmann, Sunnybrook Health Sciences Centre; Dr Janet Raboud and Dr Irving Salit, Toronto General Hospital; Dr Edward Ralph, St Joseph's Health Care; Dr Roger Sandre, Sudbury Regional Hospital; Dr Marek Smieja, Hamilton Health Sciences, McMaster University Medical Centre; and Dr Wendy Wobeser, Hotel Dieu Hospital. The authors gratefully acknowledge all of the people living with HIV who volunteered to participate in the OHTN Cohort Study and the work and support of the past and present members of the OCS Governance Committee: Adrian Betts, Anita C Benoit, Les Bowman, Tracey Conway, Patrick Cupido (Chair), Tony Di Pede, Brian Finch, Michael J Hamilton, Brian Huskins, Rick Kennedy, Ken King, Nathan Lachowsky, Joanne Lindsay, Shari Margolese, John McTavish, Colleen Price, Lori Stoltz, Darien Taylor, and Drs Ahmed Bayoumi, Evan Collins, Curtis Cooper, Clemon George, Troy Grennan, Claire Kendall, Greg Robinson and Rosie Thein. The authors thank all of the interviewers, data collectors, research associates and coordinators, nurses and physicians who provide support for data collection and extraction. The authors also thank the OHTN staff and their teams for coordination, data management and administrative support (Kevin Challacombe, Brooke Ellis, Mark Fisher, Ramandip Grewal, Robert Hudder, Veronika Moravan, Nahid Qureshi and Samantha Robinson), and the Public Health Ontario Laboratories for supporting record linkage with the HIV viral load, hepatitis $\mathrm{C}$ and syphilis test databases.

DISCLAIMER: The opinions, results and conclusions are those of the authors and no endorsement by the Ontario HIV Treatment Network or Public Health Ontario is intended or should be inferred.

DISCLOSURES AND SOURCES OF FUNDING: The authors have no relevant conflict of interests to declare. This work was supported by Canadian Institutes of Health Research (CIHR) (operating grant 111146 to ANB); a CIHR New Investigator award to ANB; and OHTN Career Scientist awards to JR and CC. The OHTN Cohort Study is funded by the AIDS Bureau, Ontario Ministry of Health and Long-Term Care. This work originated at the Ontario HIV Treatment Network.

9. Terrault NA, Dodge JL, Murphy EL, et al. Sexual transmission of hepatitis $\mathrm{C}$ virus among monogamous heterosexual couples: The HCV partners study. Hepatology 2013;57:881-9.

10. Public Health Agency of Canada (PHAC). Hepatitis C in Canada: 2005-2010 Surveillance Report. Ottawa: Centre for Communicable Diseases and Infection Control, PHAC; 2011. $<$ www.catie.ca/sites/default/files/1109-0139-Hep\%20C\%20ReportEN\%20FINAL.pdf> (Accessed May 26, 2014).

11. Alary M, Joly JR, Vincelette J, et al. Lack of evidence of sexual transmission of hepatitis $\mathrm{C}$ virus in a prospective cohort study of men who have sex with men. Am J Public Health 2005;95:502-5.

12. CATIE. A Practical Guide to Complementary Therapies for People Living with HIV. Toronto: CATIE; 2004.

13. Linas BP, Wong AY, Schackman BR, et al. Cost-effective screening for acute hepatitis $\mathrm{C}$ virus infection in HIV-infected men who have sex with men. Clin Infect Dis 2012;55:279-90.

14. Graham CS, Baden LR, Yu E, et al. Influence of human immunodeficiency virus infection on the course of hepatitis $\mathrm{C}$ virus infection: A meta-analysis. Clin Infect Dis 2001;33:562-9.

15. Berenguer J, Alejos B, Hernando V, et al. Trends in mortality according to hepatitis $\mathrm{C}$ virus serostatus in the era of combination antiretroviral therapy. AIDS Lond Engl 2012;26:2241-6.

16. Rourke SB, Gardner S, Burchell AN, et al. Cohort profile: The Ontario HIV Treatment Network Cohort Study (OCS). Int J Epidemiol 2012;42:402-11.

17. Mishra S, Boily M-C, Ng V, et al. The laboratory impact of changing syphilis screening from the rapid-plasma reagin to a 
treponemal enzyme immunoassay: A case-study from the Greater Toronto Area. Sex Transm Dis 2011;38:190-6.

18. Danta M, Brown D, Bhagani S, et al. Recent epidemic of acute hepatitis $\mathrm{C}$ virus in HIV-positive men who have sex with men linked to high-risk sexual behaviours. AIDS Lond Engl 2007;21:983-91.

19. Schmidt AJ, Rockstroh JK, Vogel M, et al. Trouble with bleeding: Risk factors for acute hepatitis C among HIV-positive gay men from Germany - a case-control study. PloS One 2011;6:e17781.

20. Wandeler G, Gsponer T, Bregenzer A, et al. Hepatitis C virus infections in the Swiss HIV Cohort Study: A rapidly evolving epidemic. Clin Infect Dis 2012;55:1408-16.

21. Sun H-Y, Chang S-Y, Yang Z-Y, et al. Recent hepatitis C virus infections in HIV-infected patients in Taiwan: Incidence and risk factors. J Clin Microbiol 2012;50:781-7.

22. Fleming DT, Wasserheit JN. From epidemiological synergy to public health policy and practice: The contribution of other sexually transmitted diseases to sexual transmission of HIV infection. Sex Transm Infect 1999;75:3-17.

23. Cooper CL, Cameron DW. Effect of alcohol use and highly active antiretroviral therapy on plasma levels of hepatitis $\mathrm{C}$ virus (HCV) in patients coinfected with HIV and HCV. Clin Infect Dis 2005;(41 Suppl 1):S105-109.

24. Remis RS, Liu J. HIV/AIDS in Ontario: Preliminary Report, 2011. Toronto: University of Toronto; 2013. <www.ohemu.utoronto.ca/doc/ PHERO2011_report_preliminary.pdf> (Accessed May 26, 2014).
25. Raboud J, Su D, Burchell AN, et al. Representativeness of an HIV cohort of the sites from which it is recruiting: Results from the Ontario HIV Treatment Network (OHTN) cohort study. BMC Med Res Methodol 2013;13:31.

26. Remis RS, Swantee C, Liu J. Report on HIV/AIDS in Ontario 2009. Toronto: University of Toronto; $2012<w w w . o h e m u . u t o r o n t o$. ca/doc/PHERO2009_report_final.pdf $>$ (Accessed April 9, 2013)

27. Gillis J, Smieja M, Cescon A, et al. Risk of cardiovascular disease associated with HCV and HBV co-infection among antiretroviraltreated HIV-infected individuals. Antivir Ther 2014;19:309-17.

28. Public Health Agency of Canada (PHAC). Canadian Guidelines on Sexually Transmitted Infections. Ottawa: Centre for Communicable Diseases and Infection Control, PHAC; 2010.

29. Centers for Disease Control and Prevention (CDC). Sexual transmission of hepatitis $\mathrm{C}$ virus among HIV-infected men who have sex with men - New York City, 2005-2010. MMWR Morb Mortal Wkly Rep 2011;60:945-50.

30. European AIDS Treatment Network (NEAT) Acute Hepatitis C Infection Consensus Panel. Acute hepatitis C in HIV-infected individuals: Recommendations from the European AIDS Treatment Network (NEAT) consensus conference. AIDS Lond Engl 2011;25:399-409.

31. Lambers FAE, Prins M, Thomas X, et al. Alarming incidence of hepatitis $C$ virus re-infection after treatment of sexually acquired acute hepatitis $\mathrm{C}$ virus infection in HIV-infected MSM. AIDS Lond Engl 2011;25:F21-27. 


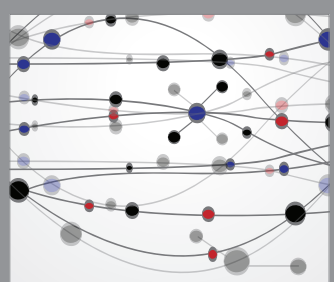

The Scientific World Journal
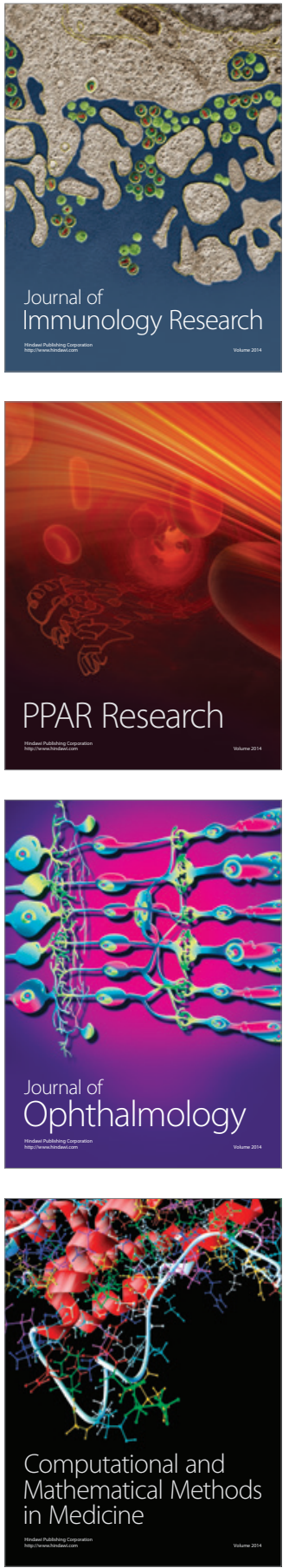

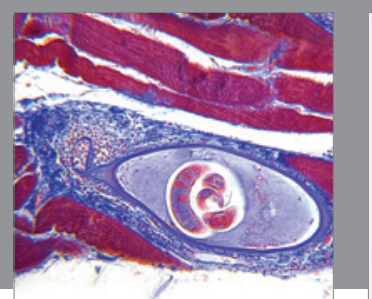

Gastroenterology Research and Practice

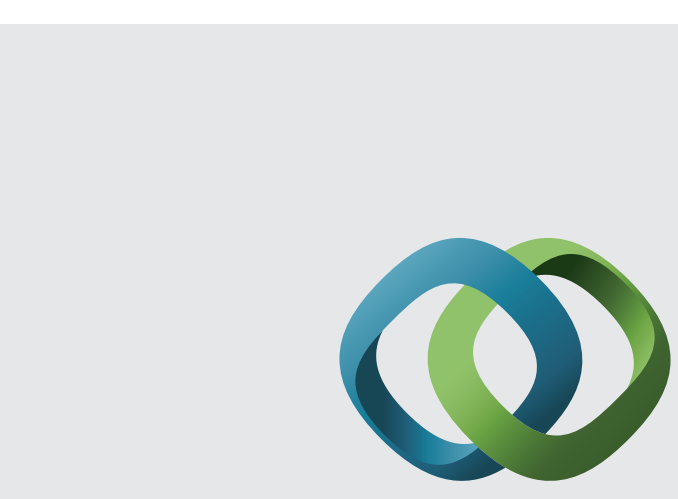

\section{Hindawi}

Submit your manuscripts at

http://www.hindawi.com
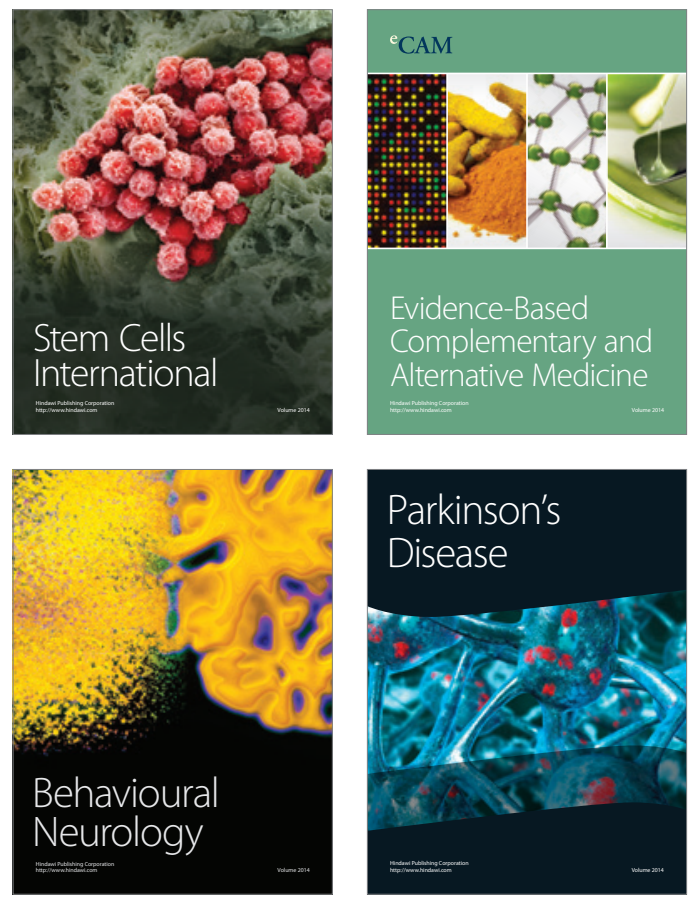
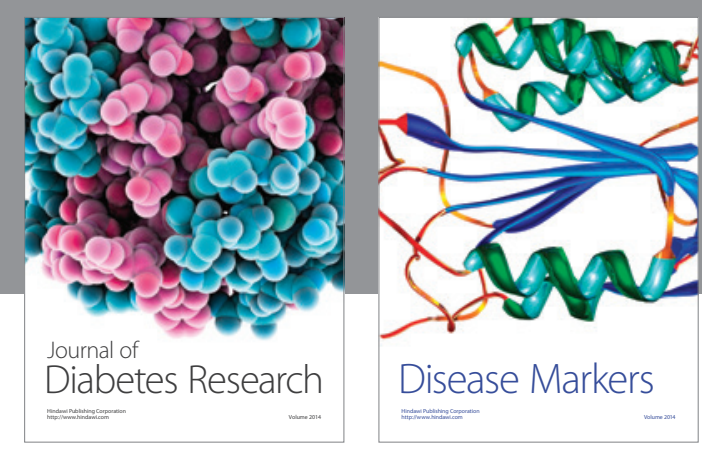

Disease Markers
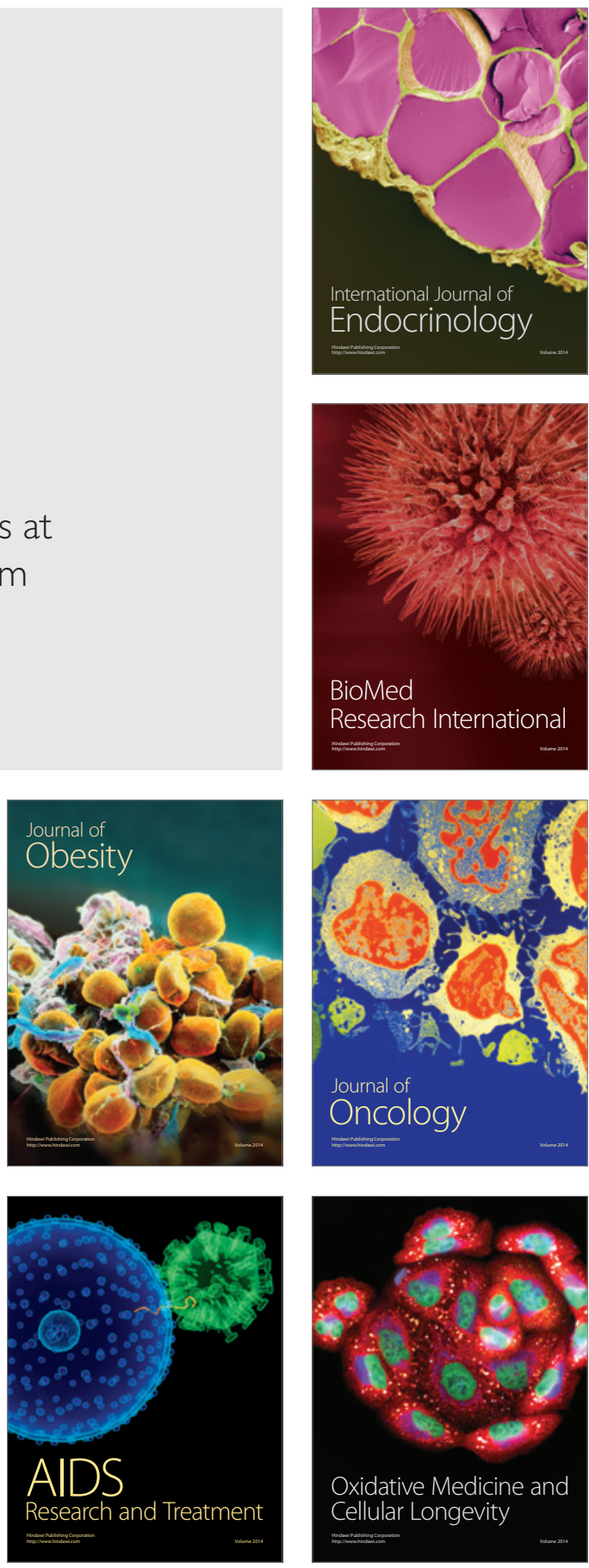